\title{
Purification, Properties, and Specificity of Rat Brain Cytosolic Fatty Acyl Coenzyme A Hydrolase
}

\author{
Constantinos G. Broustas and Amiya K. Hajra \\ Department of Biological Chemistry and Mental Health Research Institute, University of Michigan, \\ Ann Arbor, Michigan, U.S.A.
}

\begin{abstract}
Rat brain cytosolic acyl-CoA hydrolase has been purified 3,500-fold to apparent homogeneity using heat treatment, ammonium sulfate fractionation followed by anion exchange, hydrophobic interaction, and hydroxyapatite chromatography. The purified enzyme remains stable only in the presence of a high concentration $(30 \%, \mathrm{vol} / \mathrm{vol})$ of ethylene glycol. On sodium dodecyl sulfate-polyacrylamide gel electrophoresis the purified enzyme shows a single band of $40.9 \mathrm{kDa}$. However, on highperformance size-exclusion chromatography the migration rate of the enzyme corresponds with an apparent molecular mass of $148 \mathrm{kDa}$, indicating that the native enzyme may be a tetramer. The enzyme catalyzes the hydrolysis of fatty acyl-CoAs from six to 18 carbon chains long, having the highest activity for lauroyl (12:0)-CoA. For the purified enzyme the $K_{m}$ for palmitoyl-CoA is 5.8 $\mu M$ and the $V_{\max }$ is $1,300 \mu \mathrm{mol} / \mathrm{min} / \mathrm{mg}$ of protein. The enzyme is inhibited by bovine serum albumin, various detergents, lysophosphatidylcholine, and palmitoyl carnitine. Among the sulfhydryl agents, only $p$-hydroxymercuribenzoate inhibited the enzyme. The enzyme is also inactivated by treatment with a high concentration of diethyl pyrocarbonate, an active center histidine-reacting agent, but not by phenylmethylsulfonyl fluoride $(10 \mathrm{mM})$, a serine esterase inhibitor. The purified enzyme does not appear to possess any O-ester hydrolase, lysophospholipase, transacylase, or acyltransferase activity. Key Words: Palmitoyl-CoA hydrolase-Acyl-CoA hydrolase-Purification-Rat brain-Cytosol.

J. Neurochem. 64, 2345-2353 (1995).
\end{abstract}

Long chain acyl-CoA hydrolase (palmitoyl-CoA hydrolase, EC 3.1.2.2) is a ubiquitous enzyme present in all living organisms. The enzyme catalyzes the hydrolysis of fatty acyl-CoAs to free fatty acids and CoASH. In vertebrate tissues, this enzyme is present both as a soluble form in the cytosol (Kurooka et al., 1972) and as a membrane-bound form in microsomes (Berge, 1979), mitochondria (Berge and Farstad, 1979), and probably peroxisomes (Berge et al., 1984). The properties of the membrane-bound enzymes are different from those of the cytosolic enzyme. The cytosolic enzyme was first discovered to be present, in mammalian brain and other organs, by Vignais and Zabin (1958) and Srere et al. (1959). The latter authors reported that the enzyme is also present in liver and kidney but that brain had the highest activity. Kurooka et al. (1972) studied the distribution and properties of the cytosolic enzyme in various mammalian organs and showed that brain had the highest activity, followed by testis. Though normal mammalian liver has comparatively low activity of the soluble enzyme, it is highly induced in rodent liver after administration of peroxisome-proliferating agents (Kawashima et al., 1981; Miyazawa et al., 1981).

A number of laboratories have studied the properties and regulation of the crude and purified cytosolic enzyme from various sources. However, the physiological function of the enzymes is not clear. In rat and rabbit mammary gland, where the hydrolase is specific for medium chain acyl-CoAs, it probably regulates the end product of fatty acid biosynthesis by hydrolyzing the medium chain fatty acids thioesterified to the fatty acid synthase complex (Knudsen et al., 1976; Libertini and Smith, 1978). However, in most other systems, the thioester hydrolase that catalyzes the terminal step of fatty acid biosynthesis (i.e., release of the product, free fatty acid) is a member of a fatty acid synthase complex and is different from the enzyme studied here. It has been speculated that the soluble acyl-CoA hydrolase regulates the concentration of cytosolic free acyl-CoAs, which are inhibitory to many enzymes (Taketa and Pogell, 1966). However, the increase in activity of this enzyme during times of high lipid biosynthetic activity, such as during myelination or induction in liver by peroxisome-proliferating (hepatomegaly) agents, points toward a different regulatory role for this enzyme.

Received July 18, 1994; revised manuscript received October 17 , 1994; accepted November 9, 1994.

Address correspondence and reprint requests to Dr. A. K. Hajra at Neuroscience Laboratory, University of Michigan, 1103 E. Huron, Ann Arbor, MI 48104-1687, U.S.A.

Abbreviations used: CMC, critical micellar concentration; DTNB, dithio-bis(nitrobenzoic acid); lysoPtdCho, 1-acyl-sn-glycerol-3-phosphocholine; PAGE, polyacrylamide gel electrophoresis; PtdCho, 1,2diacyl-sn-glycerol-3-phosphocholine; SDS, sodium dodecyl sulfate. 
The enzyme has been reported to be purified to homogeneity from several sources such as rat liver mitochondria (Berge and Farstad, 1979), microsomes (Berge, 1979) and cytosol (after induction) (Miyazawa et al., 1981; Yamada et al., 1994), rabbit heart cytosol (Gross, 1983), and duck uropygial gland (Cheesbrough and Kolattukudy, 1985). The properties and subunit molecular weight of the purified enzyme from each source are quite different, indicating that these are isozymes. Brain cytosolic enzyme has been only partially purified as reported by different investigators. Srere et al. (1959) partially purified the enzyme from pig brain and reported that there were probably two acyl-CoA hydrolyzing enzymes, each specific for the hydrolysis of acyl-CoAs of different chain lengths. Anderson and Erwin (1971) reported that the activity of the enzyme was greater in medulla, pons, and midbrain than in cerebral cortex and caudate nucleus. These authors presented results that show that the partially purified enzyme (60-fold) is present as a dimer with a subunit molecular mass of $\sim 46 \mathrm{kDa}$. Knauer (1979) also presented evidence that the rat brain soluble hydrolase exists in monomeric $(70 \mathrm{kDa})$ and dimeric $(130 \mathrm{kDa})$ forms. Lin et al. (1984) purified rat brain cytosolic enzyme by $\sim 20$-fold and tentatively identified the enzyme to be a $65-\mathrm{kDa}$ polypeptide that showed no evidence of associated or dissociated forms.

In this study, we report the purification of the rat brain cytosolic acyl-CoA hydrolase to apparent homogeneity and present data on its properties.

\section{MATERIALS AND METHODS}

\section{Materials}

Frozen rat brains were obtained from Pel-Freez (Rogers, AR, U.S.A.). Phenyl-Sepharose CL-4B was purchased from Pharmacia Biotech (Piscataway, NJ, U.S.A.). BioGel HTP, low molecular weight protein standards, $N, N, N^{\prime}, N^{\prime}$-tetramethylenediamine, sodium dodecyl sulfate (SDS), and acrylamide/bisacrylamide were from Bio-Rad (Melville, NY, U.S.A.). TSK-G3000SW HPLC column was from TosoHaas (Montgomeryville, PA, U.S.A.). Centricon-30 filters were from Amicon (Beverly, MA, U.S.A.). Reagent grade ethylene glycol, sodium fluoride, and $\beta$-mercaptoethanol were from Fisher Scientific (Pittsburgh, PA, U.S.A.). Ultrapure ammonium sulfate and Universol ES scintillation liquid were from ICN Biochemicals (Irvine, CA, U.S.A.). Silicic acid (Unisil) was from Clarkson Chemical Company (Williamsport, PA, U.S.A.) $\left[1-^{14} \mathrm{C}\right]$ Palmitic acid was from NEN (Wilmington, DE, U.S.A.). $\left[1-{ }^{14} \mathrm{C}\right]$ Palmitoyl-CoA and palmitoyl$\mathrm{CoA}$ were prepared according to the method of Bishop and Hajra (1980). Palmitoyl glutathione and palmitoyl cysteine were prepared by the same method (Bishop and Hajra, 1980) by substituting glutathione or cysteine for CoASH. $\left[1-{ }^{14} \mathrm{C}\right]-$ Palmitoyl L-carnitine was synthesized by esterifying L-carnitine with $\left[1-{ }^{14} \mathrm{C}\right]$ palmitoyl chloride (Bremer, 1968; Bishop and Hajra, 1980). The palmitoyl L-carnitine was purified as described by Squire (1991). All other chemicals were purchased from Sigma Chemical Company (St. Louis, MO, U.S.A.).

\section{Methods}

Acyl-CoA hydrolase activity was assayed spectrophotometrically by measuring the release of free CoASH from acyl-CoA in the presence of excess' $5,5^{\prime}$-dithio-bis(2-nitrobenzoic acid) (Ellman, 1959). One milliliter of the reaction mixture contained $100 \mathrm{~m} M$ potassium phosphate, $\mathrm{pH} 7.5,0.2$ $\mathrm{m} M$ dithio-bis(nitrobenzoic acid) (DTNB), $60 \mu M$ palmitoyl$\mathrm{CoA}$, and enzyme at $37^{\circ} \mathrm{C}$. The assay was started by adding enzyme and the increase in absorbance at $412 \mathrm{~nm}$ was measured for $3 \mathrm{~min}$. A molar absorbance of $1.36 \times 10^{4} \mathrm{M}^{-1} \mathrm{~cm}^{-1}$ for the 2-nitro-5-thiobenzoate anion was used to calculate activity.

One unit of enzyme activity was defined as that hydrolyzing $1 \mu \mathrm{mol}$ of palmitoyl-CoA to free fatty acid and CoASH.

$A$ radiometric assay was also used to measure the enzyme activity, especially when the effect of thiol compounds (CoASH and dithiothreitol) was studied. Hydrolase activity was determined by measuring the release of $\left[1-{ }^{14} \mathrm{C}\right]$ palmitic acid from $\left[1-{ }^{14} \mathrm{C}\right]$ palmitoyl-CoA, which were separated from each other using Dole's extraction method (Dole, 1955). The reaction mixture $(0.4 \mathrm{ml})$ containing $100 \mathrm{~m} M$ phosphate buffer, $\mathrm{pH} 7.5,60 \mu M\left[11^{1{ }^{14}} \mathrm{C}\right]$ palmitoyl-CoA $(2,600 \mathrm{dpm} /$ $\mathrm{nmol}$ ), and enzyme was incubated at $37^{\circ} \mathrm{C}$ for $5 \mathrm{~min}$. Two milliliters of isopropanol/heptane/concentrated sulfuric acid (40:10:1) was added to the reaction mixture, mixed, and an additional $0.8 \mathrm{ml}$ of heptane and $1.2 \mathrm{ml}$ of $0.5 \mathrm{M}$ sulfuric acid was added. The mixture was mixed well and was left to stand for $10 \mathrm{~min}$ and then centrifuged at $600 \mathrm{~g}$ for $5 \mathrm{~min}$ in a tabletop Beckman TJ-6 centrifuge. Aliquots from the upper phase, containing the free palmitic acid, were transferred to scintillation vials, the solvent was removed by blowing a stream of air, and the residue was dissolved in $2 \mathrm{ml}$ of scintillation liquid (Universol) and counted in a Beckman scintillation counter.

Palmitoyl L-carnitine hydrolase activity was determined by measuring the release of $\left[1-{ }^{14} \mathrm{C}\right]$ palmitic acid from [1${ }^{14} \mathrm{C}$ ]palmitoyl L-carnitine. The assay conditions were the same as for the hydrolase assay with the exception that [1${ }^{14} \mathrm{C}$ ]palmitoyl L-carnitine $(20,000 \mathrm{dpm} / \mathrm{nmol} ; 10,50$, and 100 $\mu M)$ was used instead of $\left[1-{ }^{14} \mathrm{C}\right]$ palmitoyl-CoA.

The ability of the enzyme to hydrolyze other sulfhydryl compounds such as palmitoyl glutathione and palmitoyl cysteine was examined by using the spectrophotometric hydrolase assay and adding palmitoyl glutathione or palmitoyl cysteine to the reaction mixture instead of palmitoyl-CoA.

1-Acyl-sn-glycerol-3-[ $\left[{ }^{32} \mathrm{P}\right]$ phosphocholine ( $\left[{ }^{32} \mathrm{P}\right]$ lysoPtdCho) was prepared by enzymatic hydrolysis of 1,2-diacyl$s n$-glycerol-3- $\left[{ }^{32} \mathrm{P}\right]$ phosphocholine $\left(\left[{ }^{32} \mathrm{P}\right] \mathrm{PtdCho}\right)$ with phospholipase $A_{2}$. The labeled PtdCho was prepared by overnight incubation of SH-SY5Y neuroblastoma cells with ${ }^{32} \mathbf{P}_{i}(2$ $\mathrm{mCi}$ /culture flask) under sterile conditions. The labeled phospholipids were extracted (Lee et al., 1991) from the cells and then subjected to chromatography on silicic acid (Unisil) to isolate $\left[{ }^{32} \mathrm{P}\right] \mathrm{PtdCho}$. The lipid extract in $\mathrm{CHCl}_{3}$ was loaded onto a Unisil column $(0.5 \times 5 \mathrm{~cm})$ packed in $\mathrm{CHCl}_{3}$ and the column was eluted with $\mathrm{CHCl}_{3}$ containing increasing concentrations of methanol. PtdCho was eluted out in the fraction containing $40 \%$ methanol. The fraction was dried and the labeled PtdCho was dissolved in $2.5 \mathrm{ml}$ of diethyl ether/methanol (98:2) in a Reactivial (Pierce Chemical Co.), to which $0.25 \mathrm{ml}$ of snake venom phospholipase $\mathrm{A}_{2}$ (50 units) in $0.1 M$ Tris buffer ( $\mathrm{pH} 7.0$ ) containing calcium acetate (20 $\mathrm{m} M$ ) was added. The mixture was stirred with a magnetic stirrer for $4 \mathrm{~h}$ at room temperature and the conversion of 
PtdCho to lysoPtdCho was determined by TLC of an aliquot of reaction mixture. Ninety-eight percent of the labeled PtdCho was found to be hydrolyzed to lysoPtdCho. LysoPtdCho was extracted from the reaction mixture using Bligh and Dyer's extraction method (Bligh and Dyer, 1959) and stored in $\mathrm{CHCl}_{3}$ at $-20^{\circ} \mathrm{C}$.

Lysophospholipase activity was determined by measuring the release of glycero $\left[{ }^{32} \mathrm{P}\right]$ phosphocholine from lysoPtdCho. The incubation mixture contained $100 \mathrm{mM}$ potassium phosphate buffer (pH 7.5), $100 \mu M\left[{ }^{32} \mathrm{P}\right]$ lysoPtdCho $(2,000 \mathrm{dpm} /$ nmol), and enzyme in a total volume of $0.6 \mathrm{ml}$. Controls were run side by side without any enzyme. The reaction was performed at $37^{\circ} \mathrm{C}$ for $15 \mathrm{~min}$, and it was stopped by adding $2.25 \mathrm{ml}$ of chloroform/methanol (1:2). After mixing, an additional $0.75 \mathrm{ml} \mathrm{CHCl}_{3}$ and $0.75 \mathrm{ml}$ of water (Bligh and Dyer, 1959) were added and the two layers were separated by centrifugation. Aliquots from the organic phase (containing radioactive lysoPtdCho) and the water phase (containing the water-soluble hydrolysis products) were counted in a Beckman scintillation counter.

Transacylase activity was determined by measuring the formation of $\left[{ }^{32} \mathrm{P}\right] \mathrm{PtdCh}$ from lysoPtdCho. The incubation mixture and conditions were the same as for the lysophospholipase assay. After incubation, the radioactive lipids were extracted and washed by the method of Bligh and Dyer (1959) as described above. An aliquot of the lipid extract was applied to a TLC plate (Silica gel 60) along with standards (lysoPtdCho and PtdCho) and the plate was developed in $\mathrm{CHCl}_{3} / \mathrm{methanol} /$ acetic acid/water (100:40:12:4). The radioactive lipids were localized by autoradiography, and the spots corresponding to PtdCho $\left(R_{\mathrm{f}}=0.3\right)$ and lysoPtdCho $\left(R_{\mathrm{f}}=0.1\right)$ were scraped out. The amount of radioactivity present in them was determined by liquid scintillation counting.

LysoPtdCho:acyl-CoA acyltransferase activity was determined by measuring the formation of $\left[{ }^{32} \mathrm{P}\right] \mathrm{PtdCho}$ from $\left[{ }^{32} \mathrm{P}\right]$ lysoPtdCho and acyl-CoA. The incubation mixture contained phosphate buffer $(0.1 M, \mathrm{pH} 7.5)$, varying concentrations of $\left[{ }^{32} \mathrm{P}\right]$ lysoPtdCho $(0-100 \mu M, 2,000 \mathrm{dpm} / \mathrm{nmol})$, various acyl-CoAs $(20: 4,18: 1,16: 0$, and 2:0) at three different concentrations $(5,10$, and $20 \mu M)$, and the enzyme in a total volume of $0.6 \mathrm{ml}$. The reaction conditions were the same as for the lysophospholipase. The radioactive lipids were extracted, washed, subjected to TLC, and (after localization of the radioactive spots on the TLC) counted in the scintillation counter as described above.

\section{Enzyme purification}

All experiments were conducted at $4^{\circ} \mathrm{C}$ unless otherwise stated.

Preparation of cytosol. Frozen rat brains $(42.5 \mathrm{~g})$ were thawed and homogenized in $150 \mathrm{ml}$ of cold $\left(0-4^{\circ} \mathrm{C}\right)$ homogenization buffer $[0.25 \mathrm{M}$ sucrose, $10 \mathrm{~m} M N$-tris(hydroxymethyl)methyl-2-aminoethanesulfonic acid, $\mathrm{pH} 7.5,1 \mathrm{mM}$ EDTA, $1 \mathrm{mg} / \mathrm{ml}$ leupeptin, $1 \mathrm{~m} M$ phenylmethylsulfonyl fluoride] using a Potter-Elvehjem homogenizer and the homogenate was centrifuged at $130,000 \mathrm{~g}$ for $90 \mathrm{~min}$. The pellet was discarded and the supernatant (cytosol) was stored at $-70^{\circ} \mathrm{C}$ until used.

Heat treatment and acid precipitation. Approximately 150 $\mathrm{ml}$ of cytosol was heated in a water bath at $60-62^{\circ} \mathrm{C}$ for 5 min and then quickly cooled down to room temperature by placing it in ice. The heat-treated cytosol was acidified to pH 5.5 (monitored with a pH meter) by adding $1 \mathrm{M}$ acetic acid dropwise and with constant stirring. The mixture was centrifuged at $25,000 \mathrm{~g}$ for $20 \mathrm{~min}$ to remove the precipitated proteins. The supernatant was saved and the $\mathrm{pH}$ was carefully adjusted back to 7.5 with $2 M \mathrm{KOH}$.

Ammonium sulfate precipitation. Saturated aqueous ammonium sulfate solution (adjusted to $\mathrm{pH} 7.0$ with $1 \mathrm{M}$ $\mathrm{NH}_{4} \mathrm{OH}$ ) was added to the heat-treated cytosol to $45 \%$ saturation. The solution was stirred for $10 \mathrm{~min}$ and centrifuged at $130,000 \mathrm{~g}$ for $30 \mathrm{~min}$. Solid powdered ammonium sulfate was then added to the supernatant to $65 \%$ saturation, the solution was stirred for $10 \mathrm{~min}$ and centrifuged at 130,000 $\mathrm{g}$ for $30 \mathrm{~min}$. The resulting pellet was dissolved in $5 \mathrm{ml}$ of $20 \mathrm{~m} M$ potassium phosphate buffer, $\mathrm{pH} 7.5$, containing $20 \%$ ethylene glycol (buffer A), and dialyzed overnight against 100 volumes of the same buffer to remove contaminating ammonium sulfate.

Anion-exchange chromatography. Two milliliters (18 mg of protein) of the dialyzed sample was loaded onto a DEAESephacel column $(10 \times 80 \mathrm{~mm})$ that had previously been equilibrated with buffer $\mathrm{A}$, washed with 1 column volume of the same buffer, and eluted with an $\mathrm{NaCl}$ gradient (50$500 \mathrm{~m} M \mathrm{NaCl}$ in buffer A). One-milliliter fractions were collected at a flow rate of $0.4 \mathrm{ml} / \mathrm{min}$. The most active fractions (nos. 16-20) were combined and concentrated to $\sim 0.5$ $\mathrm{ml}$ by ultrafiltration using Centricon-30 filters.

Hydrophobic interaction chromatography. The concentrated fractions from step $3(0.5 \mathrm{ml})$ were loaded onto a phenyl-Sepharose CL-4B column $(10 \times 80 \mathrm{~mm})$ that was previously equilibrated with buffer A containing $200 \mathrm{~m} M$ $\mathrm{NaCl}$. The column was washed with 1 column volume of the same buffer and then the enzyme was eluted with a linear mixed gradient of decreasing concentration (200-0 mM) of $\mathrm{NaCl}$ and increasing concentration $(20-75 \%)$ of ethylene glycol in $20 \mathrm{~m} M$ potassium phosphate buffer, $\mathrm{pH} 7.5$. The flow rate was $0.4 \mathrm{ml} / \mathrm{min}$ and $1 \mathrm{ml}$ fractions were collected. The active fractions (nos. 38-44) were pooled and concentrated to $0.5 \mathrm{ml}$ using a Centricon-30 filter.

Hydroxyapatite chromatography. The sample from step 4 $(0.4 \mathrm{ml})$ was subsequently applied on a BioGel HTP column $(10 \times 80 \mathrm{~mm})$ that had previously been equilibrated with 20 $\mathrm{m} M$ potassium phosphate, $\mathrm{pH} 7.5$, containing $30 \%$ ethylene glycol. The column was first washed with $2 \mathrm{ml}$ of the same buffer and then $4 \mathrm{ml}$ of the above buffer containing $150 \mathrm{mM}$ $\mathrm{NaF}$. The enzyme was eluted with a linear gradient of 50$500 \mathrm{mM}$ potassium phosphate, $\mathrm{pH} 7.5$, in $30 \%$ ethylene glycol. The flow rate was $0.4 \mathrm{ml} / \mathrm{min}$ and $1-\mathrm{ml}$ fractions were collected. The active fractions (nos. 19-22) were pooled and concentrated by ultrafiltration (Centricon-30) and stored at $-70^{\circ} \mathrm{C}$.

\section{SDS-polyacrylamide gel electrophoresis (SDS-PAGE)}

SDS-PAGE was performed according to the discontinuous system of Laemmli (1970), in 10\% polyacrylamide slab gels using the Bio-Rad minigel apparatus. The samples were diluted with sample buffer $(0.06 \mathrm{M}$ Tris-HCl, $\mathrm{pH} 6.8,2 \%$ SDS, $20 \% \beta$-mercaptoethanol, $10 \%$ glycerol, and $0.02 \%$ bromophenol blue), heated at $90^{\circ} \mathrm{C}$ for $5 \mathrm{~min}$, cooled down, loaded on the gel, and electrophoresed at $200 \mathrm{mV}$ for $45 \mathrm{~min}$. After electrophoresis, the gels were stained by Coomassie Brilliant Blue G-250 as described by Neuhoff et al. (1988).

\section{Size-exclusion chromatography}

The molecular mass of the native enzyme was estimated by size-exclusion chromatography $\left(K_{\mathrm{av}} 0.47\right)$, using $100 \mathrm{~m} M$ potassium phosphate buffer, $\mathrm{pH} 7.5$, containing $30 \%$ ethyl- 
ene glycol. A TSK-3000 SW HPLC column $(0.8 \times 30 \mathrm{~cm})$ was calibrated at a flow rate of $0.4 \mathrm{ml} / \mathrm{min}$ with Bio-Rad gel filtration standards, thyroglobulin $\left(670 \mathrm{kDa}, K_{\mathrm{av}} 0.32\right), \gamma-$ globulin (158 kDa, $\left.K_{\mathrm{av}} 0.50\right)$, ovalbumin ( $\left.44 \mathrm{kDa}, K_{\mathrm{av}} 0.65\right)$, myoglobin $\left(17 \mathrm{kDa}, K_{\mathrm{av}} 0.74\right)$, and vitamin $K_{12}(1.35 \mathrm{kDa}$, $K_{\text {av }} 0.96$ ), using the same buffer.

\section{Amino acid analysis}

Amino acid analysis was done at the Protein Sequencing Facility, University of Michigan (Ann Arbor, MI, U.S.A.). Purified enzyme (15-20 $\mu \mathrm{g}$ ) was hydrolyzed with $6 \mathrm{M} \mathrm{HCl}$ at $110^{\circ} \mathrm{C}$ for $24 \mathrm{~h}$. Both amino acid standards and hydrolysate were chromatographed using an ABI Model $420 \mathrm{H}$ amino acid analyzer (Applied Biosystems, CA, U.S.A.) equipped with an on-line reverse-phase HPLC column to resolve the free amino acids. The phenylisothiocyanate method was used for precolumn derivatization.

Tryptophan content was not determined and cysteine was determined as cystine.

\section{Protein assay}

Protein was determined by the method of Lowry et al. (1951) with bovine serum albumin as standard. The trichloroacetic acid/deoxycholate method (Bensadoun and Weinstein, 1976) was used to determine protein in the hydroxyapatite fractions.

\section{RESULTS}

\section{Purification of the acyl-CoA hydrolase}

Heat treatment and acid precipitation. The first step of the purification was the heat treatment of the cytosol followed by the precipitation of the denatured proteins by lowering the $\mathrm{pH}$ with acetic acid. A sixfold purification and $>95 \%$ recovery was achieved.

Ammonium sulfate fractionation. Most $(96 \%)$ of the enzymatic activity was found to be precipitated between 45 and $65 \%$ saturation, whereas the rest of the activity precipitated before the $45 \%$ saturation and almost none above $65 \%$ saturation (see Materials and Methods). This step resulted in a threefold purification

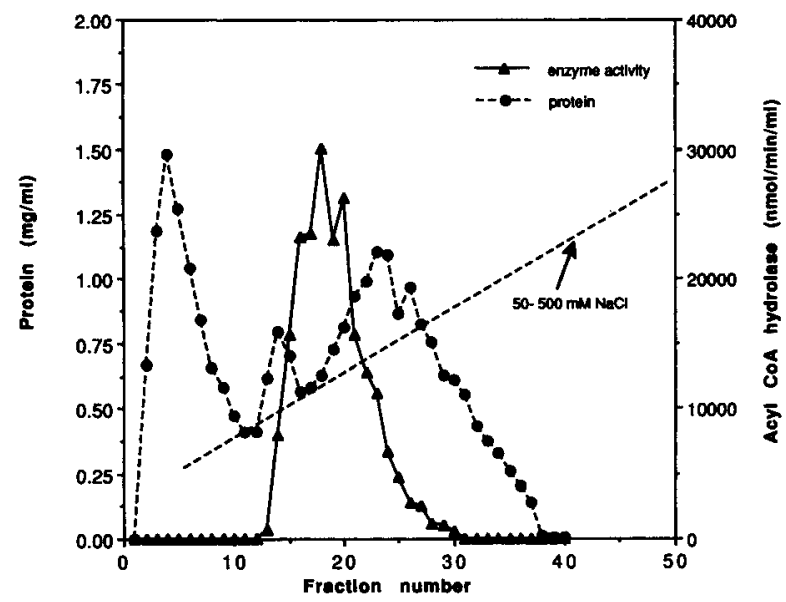

FIG. 1. DEAE-Sephacel column chromatography of acyl-CoA hydrolase. One-milliliter fractions were collected and the activity $(-)$ and protein (---) of each fraction are shown.

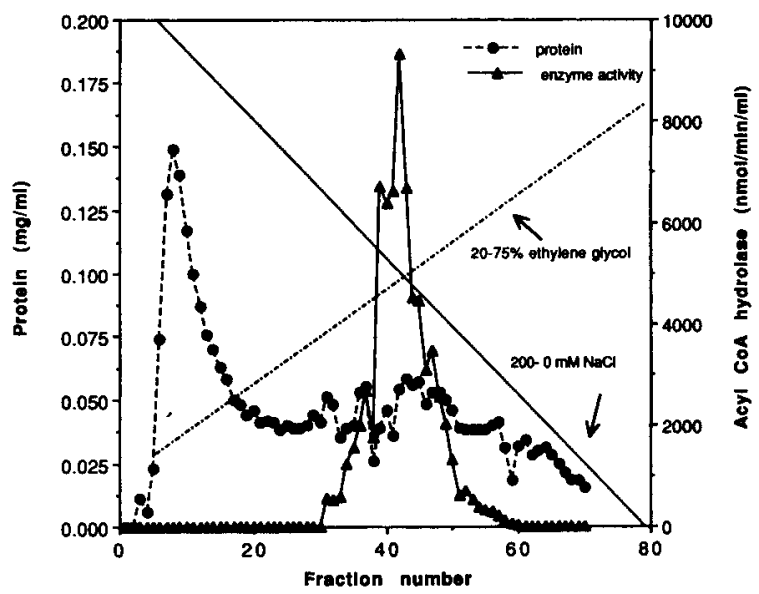

FIG. 2. Phenyl-Sepharose CL-4B column chromatography of acyl-CoA hydrolase. One-milliliter fractions were collected and the activity (-) and protein (-..-) of each fraction are shown.

(compared with the previous step) but with a $35 \%$ loss of activity.

Anion-exchange chromatography. The elution profile of the enzyme activity and protein from the DEAESephacel column is shown in Fig. 1. The enzyme was eluted at $\sim 125 \mathrm{mM} \mathrm{NaCl}$, resulting in about fourfold purification with almost $60 \%$ yield.

Hydrophobic interaction chromatography. The elution profile of the enzyme activity and protein from the phenyl-Sepharose column is shown in Fig. 2. The enzyme was eluted with a mixed gradient of decreasing ionic strength $(200-0 \mathrm{mM} \mathrm{NaCl})$ and increasing hydrophobicity (20-75\% ethylene glycol). As shown in Fig. 2, the enzyme was eluted at $\sim 100 \mathrm{mM} \mathrm{NaCl}$ and $35 \%$ ethylene glycol. In this step, a 13-fold purification with a $34 \%$ yield was achieved.

Hydroxyapatite chromatography. The elution profile of the enzyme activity and protein from the BioGel HTP hydroxyapatite column is shown in Fig. 3. The enzyme was eluted at $\sim 120 \mathrm{~m} M$ potassium phosphate buffer containing $30 \%$ ethylene glycol. In this step another fourfold purification with $12 \%$ yield was achieved. After concentration by ultrafiltration, the pure enzyme was stored at $-70^{\circ} \mathrm{C}$.

A summary of the purification is shown in Table 1. (Results are from a different experiment than that shown in Figs. 1-3.)

\section{Purity and molecular mass}

The purified preparation gave a single band after SDS-PAGE and Coomassie Brilliant Blue G-250 staining (Fig. 4). The molecular mass was estimated to be $40.9 \mathrm{kDa}$. On size-exclusion chromatography, the molecular mass of the native enzyme was deduced to be $148 \mathrm{kDa}$.

\section{Amino acid analysis}

The amino acid analysis and the composition, based on assuming the enzyme has a molecular mass of 40.9 


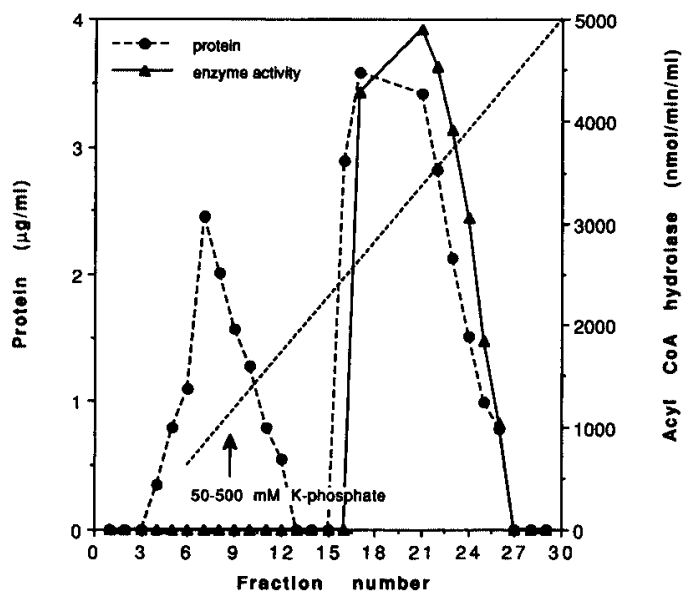

FIG. 3. BioGel HTP column chromatography of acyl-CoA hydrolase. One-milliliter fractions were collected and the activity $(\longrightarrow)$ and protein (----) of each fraction are shown.

$\mathrm{kDa}$, are given in Table 2 . The hydrophobic amino acids comprised $60 \%$ of the protein.

\section{Stability of the enzyme}

The enzyme was stable when cytosol was kept at $-70^{\circ} \mathrm{C}$ but started losing activity during the various purification steps, and ethylene glycol $(20 \%)$ was required to stabilize the enzyme from the ammonium sulfate fractionation step on. At this step the enzyme could be stored at $-70^{\circ} \mathrm{C}$ for at least 1 month without appreciable loss of activity. After the hydrophobic interaction chromatography step the enzyme became unstable and the amount of ethylene glycol necessary to stabilize it was increased to $30 \%$. The pure enzyme,

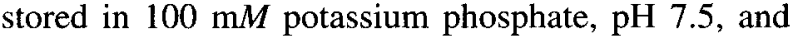
$30 \%$ ethylene glycol, at $-70^{\circ} \mathrm{C}$, lost half of its activity within 5 days. In the presence of a nonspecific protein such as bovine serum albumin $(0.5 \mathrm{mg} / \mathrm{ml})$ the loss was $35 \%$.

\section{Kinetics and substrate specificity}

By TLC analysis and the DTNB reaction, the products of hydrolysis have been shown to be free fatty acid and coenzyme $\mathrm{A}$. The reaction rate followed Michaelis-Menten kinetics and from the reciprocal plots it was estimated that the $K_{\mathrm{m}}$ for palmitoyl-CoA varied among 4.4-5.8 $\mu M$ with different enzyme preparations

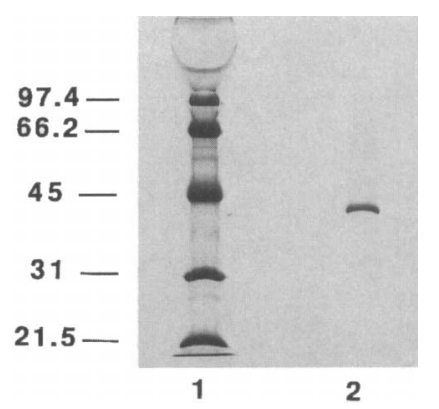

FIG. 4. SDS-PAGE of the purified acyl-CoA hydrolase. Lane 1, low molecular mass standards (Bio-Rad), phosphorylase $b$ (97.4 $\mathrm{kDa})$, bovine serum albumin $(66.2 \mathrm{kDa})$, ovalbumin $(45 \mathrm{kDa})$, carbonic anhydrase $(31 \mathrm{kDa})$, soybean trypsin inhibitor $(21.5 \mathrm{kDa})$, and lysozyme (14.4 kDa); lane 2, $1.5 \mu \mathrm{g}$ of BioGel HTP purified enzyme.

and the $V_{\max }$ was $1.3 \pm 0.2 \times 10^{3} \mu \mathrm{mol} / \mathrm{min} / \mathrm{mg}$ of protein. At palmitoyl-CoA concentrations $>70 \mu M$, inhibition of the enzyme activity was observed. The $K_{\mathrm{m}}$ values for lauroyl-CoA and arachidonoyl-CoA were 3.8 and $4.6 \mu M$, respectively. The hydrolase was active toward various saturated acyl-CoAs with six carbon atoms or longer, lauroyl-CoA being the best substrate (Fig. 5). The enzyme catalyzed the hydrolysis of long-chain unsaturated acyl-CoAs at rates comparable with that for the corresponding saturated acylCoAs. Acetyl-CoA, butyryl-CoA, malonyl-CoA, lignoceroyl-CoA, and nervonoyl-CoA were not substrates for the enzyme, whereas acetoacetyl-CoA was hydrolyzed at $8 \%$ of the rate observed with palmitoyl$\mathrm{CoA}$. The enzyme was very specific for acyl-CoAs and it did not hydrolyze $S$-palmitoyl glutathione or $S$ palmitoyl cysteine.

\section{Activators and inhibitors}

The enzyme was not inhibited by the products of the reaction as judged by using the spectrophotometric (for palmitic acid) and the radiometric (for CoA) assay. Using the latter assay it was found that $1-25 \mathrm{mM}$ dithiothreitol also had no effect on the reaction rate.

To study the effect of various agents on the enzyme activity, the hydrolase was incubated with each one of these agents for $30 \mathrm{~min}$ at $0^{\circ} \mathrm{C}$ and the remaining activity was determined radiometrically. Because the enzyme lost activity rapidly when diluted, a sample in

TABLE 1. Purification of rat brain cytosolic acyl-CoA hydrolase

\begin{tabular}{lccccr}
\hline \multicolumn{1}{c}{ Fraction } & $\begin{array}{c}\text { Protein } \\
(\mathrm{mg})\end{array}$ & $\begin{array}{c}\text { Total activity } \\
(\mu \mathrm{mol} / \mathrm{min})\end{array}$ & $\begin{array}{c}\text { Specific activity } \\
(\mu \mathrm{mol} / \mathrm{min} / \mathrm{mg} \text { of protein })\end{array}$ & $\begin{array}{c}\text { Yield } \\
(\%)\end{array}$ & $\begin{array}{c}\text { Purification } \\
(\text { fold })\end{array}$ \\
\hline Cytosol & 525 & 223 & 0.426 & 100 & 1 \\
Heat treated & 91 & 242 & 2.263 & 108 & 6 \\
$\left(\mathrm{NH}_{4}\right)_{2} \mathrm{SO}_{4}$ fractionation & 17.3 & 140 & 8.107 & 62.6 & 19 \\
DEAE-Sephacel & 4.5 & 131 & 29.36 & 58.8 & 69 \\
Phenyl-Sepharose CL-4B & 0.2 & 75.3 & 376.3 & 33.6 & 883 \\
BioGel HTP & 0.018 & 26.6 & 1478 & 11.9 & 3,470 \\
\hline
\end{tabular}


TABLE 2. Amino acid composition of rat brain cytosolic acyl-CoA hydrolase

\begin{tabular}{lc}
\hline Amino acid & mol \% \\
\hline Alanine & 11.0 \\
Arginine & 7.1 \\
Aspartic acid & 5.3 \\
Cystine & 1.9 \\
Glutamic acid & 8.5 \\
Glycine & 10.0 \\
Histidine & 3.3 \\
Isoleucine & 5.6 \\
Leucine & 9.9 \\
Lysine & 6.6 \\
Methionine & 0.2 \\
Phenylalanine & 3.7 \\
Proline & 7.0 \\
Serine & 3.3 \\
Threonine & 5.2 \\
Tryptophan & ND \\
Tyrosine & 0.7 \\
Valine & 10.6 \\
\hline
\end{tabular}

ND, not determined.

the proper dilution without any inhibitor was incubated along with the other sample. As shown in Table 3, the enzyme was not inhibited by the serine esterase inhibitor phenylmethylsulfonyl fluoride $(10 \mathrm{mM})$. The sulfhydryl group reacting agents such as $N$-ethylmaleimide $(10 \mathrm{~m} M)$, iodoacetamide $(10 \mathrm{~m} M)$, and methylmethanethiosulfonate $(10 \mathrm{mM})$ also did not inhibit the enzyme after 30-min preincubation (Table 3 ). On the other hand $p$-hydroxymercuribenzoate $(0.5 \mathrm{mM})$ abolished hydrolase activity completely (Table 3 ). After treatment with diethylpyrocarbonate, the enzyme retained $\sim 90 \%$ of its activity with $1 \mathrm{mM}$ and $\sim 10 \%$ with $10 \mathrm{~m} M$ of inhibitor (Table 3).

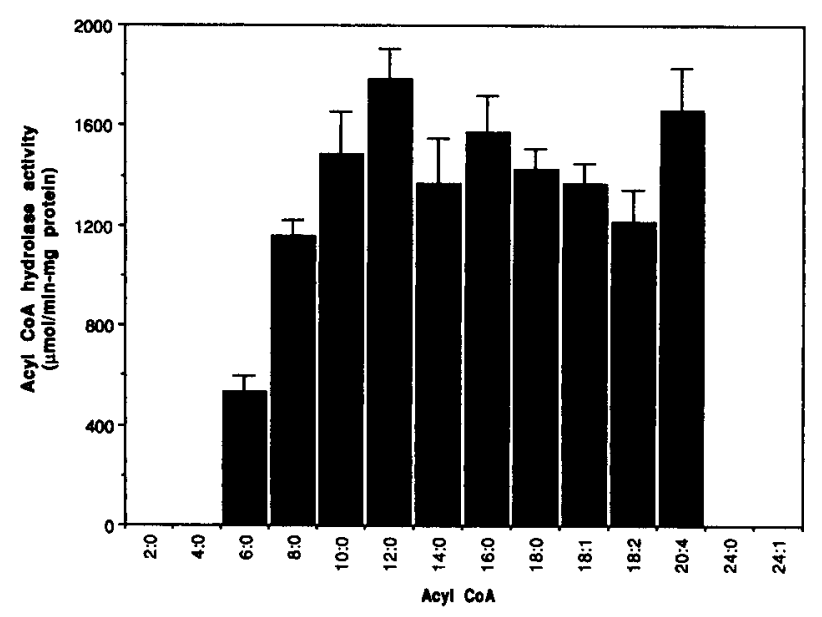

FIG. 5. Substrate specificity of acyl-CoA hydrolase. Pure enzyme was incubated with $20 \mu M$ of acyl-CoA of various chain length $\left(\mathrm{C}_{2}-\mathrm{C}_{24}\right)$ as described and the reaction rate was monitored for $2 \mathrm{~min}$ at $37^{\circ} \mathrm{C}$ with the DTNB method. Values are means \pm SD of four experiments.
TABLE 3. Effect of various reagents on acyl-CoA hydrolase activity

\begin{tabular}{lc}
\hline \multicolumn{1}{c}{ Reagent $(\mathrm{m} M)$} & $\begin{array}{c}\text { Relative activity } \\
\text { (\% of control) }\end{array}$ \\
\hline Phenylmethylsulfonyl fluoride $(10 \mathrm{~m} M)$ & 100 \\
$N$-Ethylmaleimide $(1 \mathrm{~m} M)$ & 102 \\
$N$-Ethylmaleimide $(10 \mathrm{~m} M)$ & 95 \\
Iodoacetamide $(1 \mathrm{~m} M)$ & 100 \\
Iodoacetamide $(10 \mathrm{~m} M)$ & 94 \\
Methyl methanethiosulfonate $(1 \mathrm{~m} M)$ & 88 \\
Methyl methanethiosulfonate $(10 \mathrm{~m} M)$ & 75 \\
p-Hydroxymercuribenzoate $(0.5 \mathrm{~m} M)$ & 7 \\
Diethylpyrocarbonate $(1 \mathrm{~m} M)$ & 81 \\
Diethylpyrocarbonate $(10 \mathrm{~m} M)$ & 8 \\
Calcium chloride $(1.6 \mathrm{~m} M)$ & 50 \\
Magnesium chloride $(1.6 \mathrm{~m} M)$ & 50 \\
L-Carnitine $(10 \mathrm{~m} M)$ & 100 \\
\hline
\end{tabular}

Enzyme was incubated with inhibitor for $30 \mathrm{~min}$ in ice and enzyme activity was determined by the radiometric assay. In the case of calcium and magnesium, HEPES buffer was used. The control enzyme activity was $1,650 \mu \mathrm{mol} / \mathrm{min} / \mathrm{mg}$ of protein.

Bovine serum albumin had a slight stimulatory effect at concentrations of $0.1-0.2 \mathrm{mg} / \mathrm{ml}$. At higher concentrations it had an inhibitory effect, with a $70 \%$ inhibition at $1.2 \mathrm{mg} / \mathrm{ml}$.

All detergents tested inhibited the enzyme strongly. Low concentrations of Triton X-100 $(0.01 \%)$, deoxycholate $(0.04 \%)$, SDS $(0.035 \%)$, and octylglucoside $(0.3 \%)$ resulted in $50 \%$ loss of activity. At concentrations $<0.01 \%$ for deoxycholate and SDS, and $0.1 \%$ for octylglucoside, a slight stimulation was observed.

LysoPtdCho inhibited the enzyme at low concentrations of palmitoyl-CoA. This inhibition was competitive because it was relieved at higher concentrations of acyl-CoA (Fig. 6). Lysophosphatidylinositol also inhibited the enzyme but not as strongly as lysoPtdCho. At lysoPtdCho concentrations of $60 \mu \mathrm{g} / \mathrm{ml}$ the enzyme lost $\sim 75 \%$ of its activity; whereas with lysophosphatidylinositol at the same concentration, only $35 \%$ of its activity was lost (Fig. 6). Whether the purified enzyme catalyzes the hydrolysis of lysoPtdCho to fatty acids and $s n$-glycero-3-[ $\left.{ }^{32} \mathrm{P}\right]$ phosphocholine was investigated by incubating the enzyme with lysoPtdCho, as described above. Compared with the controls (no enzyme or zero time incubation), no increase in radioactivity in the aqueous layer was seen, indicating a watersoluble ${ }^{32} \mathrm{P}$-labeled product or products were not formed. In similar experiments (see Materials and Methods) using $\left[{ }^{32} \mathrm{P}\right] l y s o P t d C h o$, the enzyme showed no transacylase (transfer of acyl group from one molecule of lysoPtdCho to another molecule to form PtdCho) or acyl-CoA:lysoPtdCho acyltransferase activity.

Palmitoyl L-carnitine inhibited the enzyme (Fig. 7), showing the same inhibition pattern as lysoPtdCho. The shorter chain acylcarnitines (i.e., octanoyl- and decanoylcarnitine) and $L$-carnitine had no effect on the rate of hydrolysis of palmitoyl-CoA (Fig. 7). Whether 

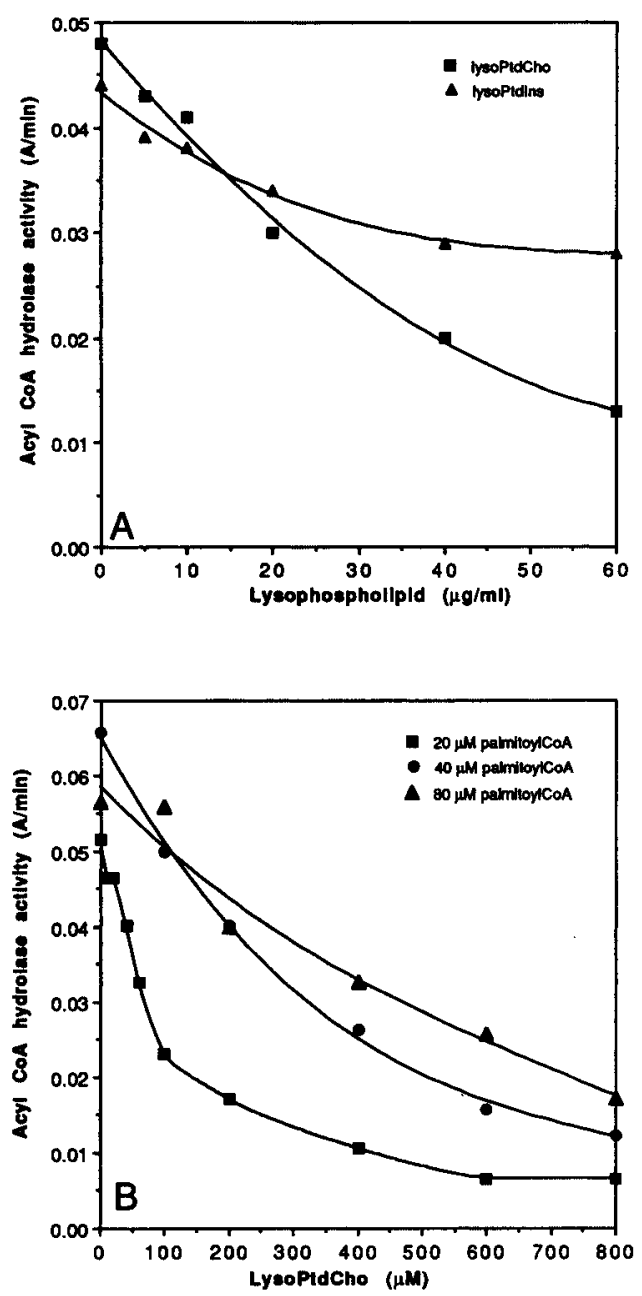

FIG. 6. Effect of lysophospholipids on acyl-CoA hydrolase. A: Effect of lysoPtdCho and lysophosphatidylinositol (lysoPtdlns) on the reaction rate of the enzyme. Palmitoyl-CoA concentration was $20 \mu \mathrm{M}$. B: Effect of lysoPtdCho on the enzyme at three different concentrations of palmitoyl-CoA.

the enzyme also catalyzes the hydrolysis of palmitoyl L-carnitine was tested by incubating $\left[1-{ }^{14} \mathrm{C}\right]$ palmitoyl L-carnitine with the purified enzyme and then the formation of $\left[1-{ }^{14} \mathrm{C}\right]$ palmitic acid was examined by solvent partition (Dole, 1965; Squire, 1991) as described above. No formation of free $\left[1-{ }^{14} \mathrm{C}\right]$ palmitic acid was seen.

As shown in Table $3, \mathrm{CaCl}_{2}$ and $\mathrm{MgCl}_{2}$ inhibited the enzyme; $1.6 \mathrm{~m} M$ calcium or magnesium resulted in 50\% loss of the enzyme activity. Calcium concentrations $<100 \mu M$ had no effect on the reaction rate.

\section{DISCUSSION}

Using a combination of protein purification techniques, the rat brain cytosolic acyl-CoA hydrolase has been purified by $\sim 3,500$-fold to homogeneity. From the purification factor, it may be deduced that the en- zyme constitutes $\sim 0.03 \%$ of cytosolic protein. Although the enzyme is a soluble protein, after partial purification it remains stable only when kept in a hydrophobic environment (i.e., in the presence of ethylene glycol) indicating the hydrophobic nature of the enzyme (Lin et al., 1984). This is also seen in the steps necessary for purification and in the amino acid composition of the enzyme where the hydrophobic amino acids (valine, isoleucine, leucine, alanine) constitute $\sim 60 \%$ of the total amino acid content of the protein. The crucial step in the purification is the use of hydrophobic interaction chromatography on phenylSepharose CL-4B, using a mixed gradient (decreasing ionic strength and increasing dielectric constant) elution procedure (Fig. 2) where the enzyme elutes as a single peak. Unlike the crude cytosolic enzyme, the
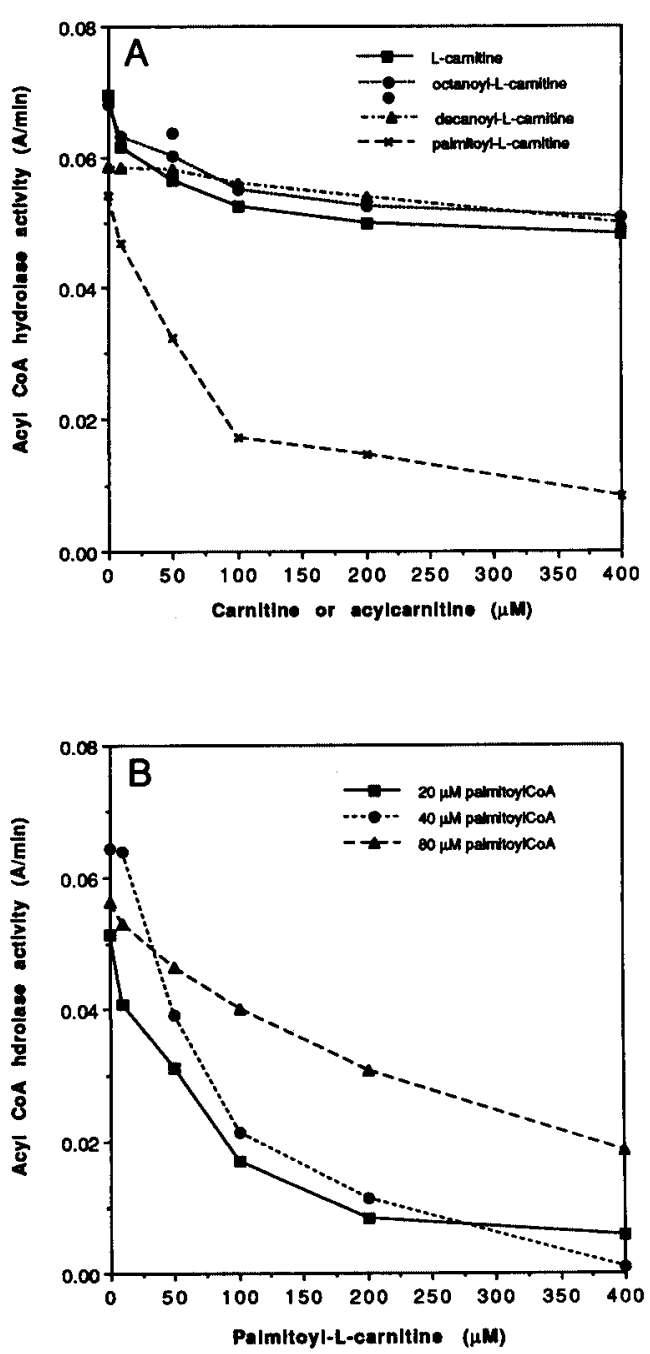

FIG. 7. Effect of L-carnitine and acylcarnitine on acyl-CoA hydrolase activity. A: Effect of L-carnitine, octanoyl L-carnitine, decanoyl L-carnitine, and palmitoyl L-carnitine on the reaction rate. Palmitoyl-CoA concentration was $20 \mu M$. B: Effect of palmitoyl $L$-carnitine on the enzyme at various concentrations of palmitoylCoA. 
purified enzyme is very unstable, even when stored in ethylene glycoı-containing buffer.

By SDS-PAGE the molecular mass of the enzyme was deduced to be $40.9 \mathrm{kDa}$. This figure is different from those estimated by Lin et al. (1984) who estimated a mass of $65 \mathrm{kDa}$ from the partially purified enzyme, and by Knauer (1979) who used brain cytosol (i.e., crude enzyme) to estimate it at $70 \mathrm{kDa}$. However, the molecular mass reported here is similar to that reported for the induced enzyme or enzymes in rat liver [i.e., $41 \mathrm{kDa}$ reported by Miyazawa et al. (1981) and 36 and $42 \mathrm{kDa}$ by Yamada et al. (1994)]. The rat heart cytosolic enzyme had smaller molecular mass [23 kDa (Gross, 1983)]. On size-exclusion chromatography, the purified enzyme has an apparent molecular mass of $148 \mathrm{kDa}$, indicating that the native enzyme is probably a tetramer. The enzyme has broad chain length specificity with respect to various acyl-CoAs, hydrolyzing medium and long chain acyl-CoAs but having very little activity toward very long chain $\left(>\mathrm{C}_{22}\right)$ or short chain $\left(<\mathrm{C}_{6}\right)$ acyl-CoAs. This broad specificity of the purified enzyme shows that contrary to earlier speculation (Srere et al., 1959) only one cytosolic brain acyl-CoA hydrolase is responsible for the hydrolysis of varieties of acyl-CoAs.

The $K_{\mathrm{m}}$ of the enzyme for various acyl-CoAs is low $(\sim 5 \mu M)$ and the $V_{\max }$ is very high (up to $1,700 \mu \mathrm{mol} /$ $\mathrm{min} / \mathrm{mg}$ of protein) compared with other purified acylCoA hydrolases such as microsomal $[1.15 \mu \mathrm{mol} / \mathrm{min} /$ mg of protein; (Berge, 1979)] or mitochondrial [1.7 $\mu \mathrm{mol} / \mathrm{min} / \mathrm{mg}$ of protein (Berge and Farstad, 1979)] and soluble rat heart $[24 \mu \mathrm{mol} / \mathrm{min} / \mathrm{mg}$ of protein (Gross, 1983)] acyl-CoA hydrolases. The induced rat liver acyl-CoA hydrolase is reported to have high specific activity $[250 \mu \mathrm{mol} / \mathrm{min} / \mathrm{mg}$ of protein (Miyazawa et al., 1981; Yamada et al., 1994)] but not as high as the purified enzyme reported here. For the monomeric enzyme $(40.9 \mathrm{kDa})$ it may be calculated that the $k_{\text {cat }}$ is $\sim 1,200 \mathrm{~s}^{-1}$ so that $k_{\mathrm{cat}} / K_{\mathrm{m}}=231,000 \mathrm{~s}^{-1} \mathrm{~m} M^{-1}$ for palmitoyl-CoA indicating that it is also a very efficient hydrolase.

Barden and Cleland (1969) working with the rat liver enzyme suggested that the preferred substrate for the hydrolase were acyl-CoAs in the micellar form. This was based upon the assumption that the critical micellar concentration (CMC) of palmitoyl-CoA is 3.6 $\mu M$ (Barden and Cleland, 1969). However, recent work indicates that the CMC of palmitoyl-CoA is somewhere between 50 and $70 \mu M$ (Constantinides and Steim, 1985). From the kinetic properties it may then be deduced that monomeric acyl-CoAs are the preferred substrate of the enzyme, and the enzyme is probably inhibited by the acyl-CoA micelles as seen by its inhibition at high $(>70 \mu M)$ palmitoyl-CoA concentration. This is also seen by the inhibition of the enzyme activity by bovine serum albumin, which binds acylCoAs, lowering the concentration of free acyl-CoA in the incubation mixture. Except for a slight stimulation (due to breaking up of the micelles?) at low concentra- tion $(<0.2 \mathrm{mg} / \mathrm{ml})$, albumin inhibits the enzyme strongly, which also indicates that the enzyme catalyzes the hydrolysis of free, but not protein-bound, acyl-CoAs.

A number of acyl-CoA hydrolases have been shown to be inhibited by serine-esterase inhibitors (Cheesbrough and Kolattukudy, 1985). However, brain acylCoA hydrolase is unaffected by phenylmethylsulfonyl fluoride, indicating that it is probably not a serine thioesterase. On the other hand, diethylpyrocarbonate inhibited the enzyme, albeit at only very high concentrations, indicating that there may be a histidine residue at the active center of the enzyme. $N$-Ethylmaleimide, iodoacetamide, or methyl methanethiosulfonate also had no effect on the enzyme activity. In contrast, $p$ hydroxymercuribenzoate was a very potent inhibitor of the enzyme, implying that this reagent denatures the enzyme after reacting with a nonessential thiol group or groups. Divalent cations such as $\mathrm{Ca}^{2+}, \mathrm{Mg}^{2+}$, and $\mathrm{Mn}^{2+}$ inhibit the enzymatic reaction but only at high, nonphysiological concentrations. Unlike the mitochondrial acyl-CoA hydrolase (Berge and Farstad, 1979), the brain enzyme is not inhibited by L-carnitine (Fig. 7). Palmitoyl L-carnitine, but not shorter chain acyl Lcarnitines, inhibits the enzyme. As shown, palmitoyl carnitine is not hydrolyzed by the enzyme. Therefore, it appears that this inhibition is due to the detergent action of palmitoyl L-carnitine.

All detergents tested, Triton X-100, SDS, deoxycholate, and octylglucoside, inhibit the enzyme strongly. Lysophospholipids are also strong inhibitors of the enzymatic reaction, possibly also due to their detergent properties, especially at higher concentrations. However, lysoPtdCho is strongly inhibitory even at very low concentrations (Fig. 6), indicating that such inhibition may have some physiological significance, i.e., conservation of the substrate (acyl-CoA) for the acyltransferase reaction to convert lysophospholipids to phospholipids when the concentration of the lysolipid becomes elevated.

The enzyme is very specific for the hydrolysis of acyl-CoA. Other thioester compounds such as palmitoyl glutathione and palmitoyl cysteine are not hydrolyzed. Unlike the heart enzyme (Gross, 1983), the purified brain enzyme does not have any $O$-acyl esterase activity toward lysoPtdCho. The enzyme also does not hydrolyze acylcarnitine. As presented above, the enzyme also does not have any transacylase or acyltransferase activity when lysoPtdCho is used as the substrate.

Miyazawa et al. (1981) reported that the antibody against the induced rat liver enzyme cross-reacted with the rat brain cytosolic enzyme. Very recently, Yamada et al. (1994) also reported that antibodies raised against one of the induced rat liver acyl-CoA hydrolases reacts with the brain enzyme. However, the properties of the rat brain enzyme are quite different from those of induced rat liver enzyme with respect to inducibility (brain enzyme is not induced by hypolipidemic 
agents), heat stability, substrate specificity, and inhibition by ATP and divalent cations. These two enzymes are probably similar with some common sequence homology, which could only be proven by establishing their primary structures.

The physiological function of this highly active hydrolase is not clear. The enzyme has been shown not to hydrolyze the fatty acid moiety from $S$-acyl proteins (Bizzozero et al., 1992; Camp and Hofmann, 1993), and as shown here it cannot act as an acyltransferase, transacylase, or $O$-acyl hydrolase. From the substrate specificity and developmental profile (Smith and Sun, 1981) and its induction in liver by peroxisomal proliferators, it may be postulated that one of the functions of the enzyme is to regulate peroxisomal and mitochondrial $\beta$-oxidation of fatty acids by regulating the intracellular acyl-CoA and free $\mathrm{CoA}$ concentrations, ultimately controlling the biogenesis of membrane lipids from acetyl-CoA.

Acknowledgment: We thank Leslie Larkins for the preparation of the manuscript. This work was supported by grant NS 15747 from the National Institutes of Health.

\section{REFERENCES}

Anderson A. D. and Erwin V. D. (1971) Brain acyl-coenzyme A hydrolase: distribution, purification and properties. J. Neurochem. 18, $1179-1186$.

Barden R. E. and Cleland W. W. (1969) 1-Acylglycerol 3-phosphate acyltransferase from rat liver. J. Biol. Chem. 244, 3677-3684.

Bensadoun A. and Weinstein D. (1976) Assay of proteins in the presence of interfering materials. Anal. Biochem. 70, 241-250.

Berge R. K. (1979) Purification and characterization of a long-chain acyl-CoA hydrolase from rat liver microsomes. Biochim. Biophys. Acta 574, 321-333.

Berge R. K. and Farstad M. (1979) Purification and characterization of long-chain acyl-CoA hydrolase from rat liver mitochondria. Eur. J. Biochem. 96, 393-401.

Berge R. K., Flatmark T., and Osmundsen H. (1984) Enhancement of long-chain acyl-CoA activity in peroxisomes and mitochondria of rat liver by peroxisomal proliferators. Eur. J. Biochem. 141, 637-644.

Bishop J. E. and Hajra A. K. (1980) A method for the chemical synthesis of ${ }^{14} \mathrm{C}$-labeled fatty acyl coenzyme As of high specific activity. Anal. Biochem. 106, 344-350.

Bizzozero O. A., Leyba J., and Nunez D. J. (1992) Characterization of proteolipid protein fatty acylesterase from rat brain myelin J. Biol. Chem. 267, 7886-7894.

Bligh E. G. and Dyer W. J. (1959) A rapid method of total lipid extraction and purification. Can. J. Biochem. 37, 911-917.

Bremer J. (1968) Long-chain acylcarnitines. Biochem. Prepns. 12, $69-73$.

Camp L. A. and Hofmann S. L. (1993) Purification and properties of a palmitoyl-protein thioesterase that cleaves palmitate from H-Ras. J. Biol. Chem. 268, 22566-22574.

Cheesbrough T. M. and Kolattukudy P. E. (1985) Purification and characterization of a fatty acyl-CoA hydrolase from the uropygial glands of Peking ducks (Anas domesticus). Arch. Biochem. Biophys. 237, 208-216.
Constantinides P. P. and Steim J. M. (1985) Physical properties of fatty acyl CoA. J. Biol. Chem. 260, 7573-7580.

Dole V. P. (1955) A relation between non-esterified fatty acids in plasma and the metabolism of glucose. J. Clin. Invest. 35, 150154.

Ellman G. L. (1959) Tissue sulfhydryl group. Arch. Biochem. Biophys. 82, 70-77.

Gross R. W. (1983) Purification of rabbit myocardial cytosolic acylCoA hydrolase, identity with lysophospholipase, and modulation of enzymic activity by endogenous cardiac amphiphiles. Biochemistry 22, $5641-5646$.

Kawashima Y., Katoh H., and Kozuka H. (1981) Effect of clofibric acid administration on palmitoyl-CoA hydrolase activity in rat liver. J. Pharmacobiodyn. 4, 711-717.

Knauer T. E. (1979) Factors affecting the activity and stability of the palmitoyl-coenzyme A hydrolase of rat brain. Biochem. $J$. 179, 515-523.

Knudsen J., Clark S., and Dils R. (1976) Purification and some properties of a medium-chain acyl-thioester hydrolase from lactating-rabbit mammary gland which terminates chain elongation in fatty acid synthesis. Biochem. $J$. 160, 683-691.

Kurooka S., Hosoki K., and Yoshimura Y. (1972) Some properties of long fatty acyl-coenzyme A thioesterase in rat organs. $J$. Biochem. (Tokyo) 71, 625-634.

Laemmli U. K. (1970) Cleavage of structural proteins during the assembly of the head of bacteriophage T4. Nature 227, $680-$ 685.

Lee C., Fisher S. K., Agranoff B. W., and Hajra A. K. (1991) Quantitative analysis of molecular species of diacylglycerol and phosphatidate formed upon muscarinic receptor activation of human SK-N-SH neuroblastoma cells. J. Biol. Chem. 266, 22837-22846.

Libertini L. J. and Smith S. (1978) Purification and properties of a thioesterase from lactating rat mammary gland which modifies the product specificity of fatty acid synthase. J. Biol. Chem. 253, 1393-1401.

Lin A. Y., Sun G. Y., and MacQuarrie R. (1984) Partial purification and properties of long-chain acyl-CoA hydrolase from rat brain cytosol. Neurochem. Res. 9, 1571-1591.

Lowry O. H., Rosebrough N. J., Farr A. L., and Randall R. J. (1951) Protein measurement with Folin phenol reagent. J. Biol. Chem. 193, 265-275.

Miyazawa S., Furuta S., and Hashimoto T. (1981) Induction of a novel long-chain acyl-CoA hydrolase in rat liver by administration of peroxisomal proliferators. Eur. J. Biochem. 117, 425430.

Neuhoff V., Arold N., Taube D., and Ehrhardt W. (1988) Improved staining of proteins in polyacrylamide gels including isoelectric focusing gels with clear background at nanogram sensitivity using Coomassie Brilliant Blue G-250 and R-250. Electrophoresis $9,255-262$

Smith R. E. and Sun G. Y. (1981) Metabolism of acyl-CoA in the developing rat brain. Dev. Neurosci. 4, 337-344.

Squire R. S. T. (1991) Synthesis and purification of radioactive fatty acylcarnitines of high specific activity. Anal. Biochem. 197, 104-107.

Srere P. A., Seubert W., and Lynen F. (1959) Palmitoyl coenzyme A deacylase. Biochim. Biophys. Acta 33, 313-319.

Taketa K. and Pogell B. M. (1966) The effect of palmityl coenzyme A on glucose-6-phosphate dehydrogenase and other enzymes. J. Biol. Chem. 241, 720-726.

Vignais P. V. and Zabin I. (1958) Synthesis and properties of palmityl adenylate, palmityl coenzyme $\mathrm{A}$ and palmityl glutathione. Biochim. Biophys. Acta 29, 263-269.

Yamada J., Matsumoto I., Furihata T., Sakuma M., and Suga T. (1994) Purification and properties of long-chain acyl-CoA hydrolases from the liver cytosol of rats treated with peroxisomal proliferator. Arch. Biochem. Biophys. 308, 118-125. 